Supplement of Saf. Nucl. Waste Disposal, 1, 221-223, 2021

https://doi.org/10.5194/sand-1-221-2021-supplement

(C) Author(s) 2021. CC BY 4.0 License.

Supplement of

\title{
Transdisciplinary disposal governance - Learning and reflexion in and between organisations and through participation of the public
}

Melanie Mbah et al.

Correspondence to: Melanie Mbah (m.mbah@oeko.de)

The copyright of individual parts of the supplement might differ from the article licence. 


\section{Transdisciplinary disposal governance - Learning and reflexion in and between organisations and through participation of the public}

Melanie Mbah, Bettina Brohmann, Silvia Schütte safeND

Berlin, 12.11.2021
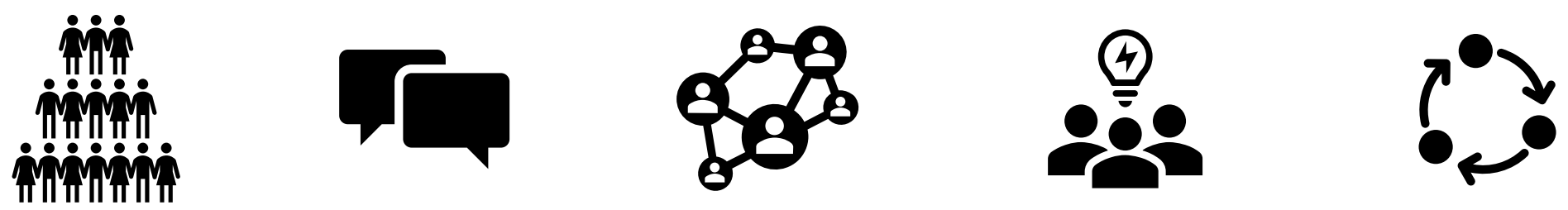
1. Why transdisciplinary?

2. What does learning in and between organisations mean?

3. What does learning mean in the German Site Selection Act?

4. How can participatory and transdisciplinary formats contribute to learning?

5. Why is context crucial? 


\section{Why transdisciplinary?}

- Nuclear disposal is part of a transformative process (part of energy transition and induces societal and political transformations)

$\rightarrow$ cooperation is crucial for success

- Transdisciplinary approaches are suitable to collaboratively work on (complex) real-world problems

$\rightarrow$ e.g. concepts for learning and reversibility, participation, etc.

\section{E.g., the project TRANSENS tests in different fields how and if transdisciplinary approaches can contribute to better solutions regarding nuclear disposal.}


2. What does learning in and between organisations mean?

- Learning $=$ is a process which generates long-term changes in attitudes and behaviours (intentional and implicit learning processes) [Müsseler 2005]

- For collective learning are individual (e.g. cognitions, attitudes) and collective (e.g. culture, structure/hirachy) factors crucial

- Learning organisations do positively and actively support error culture (e.g. through experimentation) [Wolff et al. 2018]

\section{Mutual learning processes and the development of (collective) td knowledge are key aspects of induced transformations.}


2. What does learning in and between organisations mean?

Requirements for learning (i.a. in td settings):

- Optimisation of knowledge management

- Realization of implicit knowledge

- Adjustment of structural characteristics and management culture

- Cooperative and collaborative working culture = networks with strong and weak ties

\section{Approve interferences between all actors (and the public).}

[Agyris/Schön 2018; Binner 2018; Park/Kim 2018; Senge 2017] 
3. What does learning mean in the German Site Selection Act?

- Citizens are to be involved as "co-designers of the procedure" (§ 5 (1) 2 StandAG)

- $\S 5$ (3) stipulates a further development of the participation procedure with the public

\section{Need for participation that goes beyond information and consultation!}




\section{Öko-Institut e.V.}

3. What does learning mean in the German Site Selection Act?

direct contextual actors (e.g. BMU)

indirect contextual actors (e.g. NGO, Sciences)

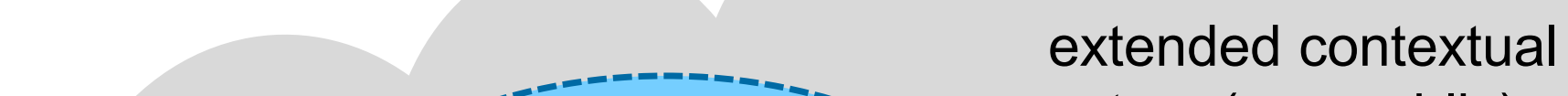
actors (e.g. public) 
4. How can participatory and transdisciplinary formats contribute to learning?

- To collaboratively design concepts, produce knowledge and continually evaluate the procedure

$\rightarrow$ information and communication wide spread at „equal“ basis

- On different levels (local, regional, national) and topics (e.g. regional planning)

$\rightarrow$ including local experts and professional public

- Context specific and in different - also experimental - formats

$\rightarrow$ as integral part of the long-term procedure

- Focused on transformative impacts (of different subsystems)

$\rightarrow$ find out about needs and expectations as orientation for further steps and conceptual work 


\section{Why is context crucial?}

- Infrastructures cause long-term changes

$\rightarrow$ several places are already affected, some will be affected in the near and far future

- Place identities shape attitudes towards and perceptions of technologies and innovations (e.g. energy production plants or nuclear facilities)

$\rightarrow$ there is a need to understand spatial change better by integrating place specific characteristics

\section{Td approaches need to be adapted to contexts that they can support mutual learning processes which may lead to better concepts and decisions}


Thank you for your attention! m.mbah@oeko.de

Do you have any questions? 


\section{Selected References}

Argyris, C.: Double loop learning in organizations, Harvard Bus. Rev., 115-125, 1977.

Argyris, C.; Schön, D. A.: Die lernende Organisation. Grundlagen, Methode, Praxis. Unter Mitarbeit von Wolfgang Rhiel. Sonderausgabe Management-Klassiker. Stuttgart: Schaefer-Poeschel, 2018.

Binner, H. F.: Organisation 4.0: MITO-Konfigurationsmanagement. Wiesbaden: Springer Vieweg, 2018.

Brohmann, B., Mbah, M., Schütte, S., Ewen, C., Horelt, M.-A., Hocke, P., and Enderle, S.: Öffentlichkeitsbeteiligung bei der Endlagersuche: Herausforderungen eines generationenübergreifenden, selbsthinterfragenden und lernenden Verfahrens. Schlussfolgerungen und Empfehlungen, BASE-004/21, BASE, Berlin, urn:nbn:de:0221-2021051027029, 2021.

Ewer, W., Thienel, T.: Rechtsgutachten zur frühzeitigen Öffentlichkeitsbeteiligung in der ersten Phase des Standortauswahlverfahrens und zu Fragen des Rechtsschutzes im Auftrag des Nationalen Begleitgremiums, 27 May 2019, Weissleder - Ewer Rechtsanwälte - Partnerschaft mbB, Kiel, 2019.

Kuhbier, J.: Kurzgutachten zur Auslegung des $\S 9$ StandAG, Im Auftrag des Bundesamtes für die Sicherheit der nuklearen Entsorgung, 2 April 2020, Rechtsanwalt Jörg Kuhbier, Hamburg, 2020.

NBG: Ein neuer Weg hat sich bewährt. Unsere Begleitung des Standortauswahlverfahrens, Rückblick und Ausblick, Berlin, 2019.

NBG: Empfehlungen des Nationalen Begleitgremiums zur Öffentlichkeitsbeteiligung in der Endlagersuche. Öffentliches Fachgespräch mit dem Ausschuss für Umwelt, Naturschutz und nukleare Sicherheit, Berlin, 2021.

Park, S., Kim, E.-S.: Fostering organisational learning through leadership and knowledge sharing. Journal of Knowledge Management 22 (6), 1408-1423, 2018.

Senge, P. M.: Die fünfte Disziplin. Kunst und Praxis der lernenden Organisation. Stuttgart: Schaefer-Poeschel, 2017. 